\title{
鉛直方向に振動する水平板を用いた消波機構とフィードバック制御に基づく 水槽内の定在波抑制
}

\author{
Disturbance attenuation for standing wave oscillation in a water wave tank \\ based on feedback control with a vertical-vibrating plate \\ Takashi HIROTA*1 ${ }^{* 1}$ Yasuhide KOBAYASHI*2 and Naoyuki INUKAI*3 \\ ${ }^{* 1}$ Graduate School of Mechanical Engineering, Nagaoka University of Technology \\ 1603-1 Kamitomioka-cho, Nagaoka-shi, Niigata, 940-2188 Japan \\ ${ }^{* 2, * 3}$ Faculty of Engineering, Nagaoka University of Technology \\ 1603-1 Kamitomioka-cho, Nagaoka-shi, Niigata, 940-2188 Japan
}

廣田 貴士 $* 1$, 小林 泰秀 $* 2$, 尤飼直之 $* 3$

\section{Received 6 July 2014}

\begin{abstract}
This paper proposes active control system based on feedback control and an wave generating actuator with a verticalvibrating plate, in order to attenuate standing-wave oscillation by unkown disturbance contamination in water wave tank. The validity of the system is examined by control experiments. The water wave tank is about $0.9 \mathrm{~m}$ in length, and has two actuators symmetrically located in the tank (one for disturbance generation and one for attenuation control) and two waterlevel sensors (one for control measurement and one for performance evaluation). First, the plant model is identified based on frequency response experiments, and the validity of the model is shown by a numerical analysis with the boundary element method. Secondly, the feedback controller is systematically designed by $\mathscr{H}_{\infty}$ control synthesis so that the robust stability is guaranteed against plant uncertainty, and the validity of the system is shown based on the symmetry locations of actuators. Finally, control experiments are examined by using sinusoidal and random signals as unknown disturbance. It has been shown that the frequency components of resonance from the 1st to 4th modes are reduced by $20 \% \sim 60 \%$, which shows the desired performance of the proposed system to attenuate standing-wave oscillation.
\end{abstract}

Key words : Water wave control, $\mathscr{H}_{\infty}$ control, Vertical vibrating plate, Standing wave oscillation, Boundary element method

\section{1.は じめに}

波の制御には消波と造波があり，用途に応じて产の技術は使い分けられる．消波機構の用途には防波堤がある 防波堤は，大別すると，堤防のような構造物を海中に設置するタイプ, 潜堤や没水平板のように構造物を水面下に 設置するタイプがある . 前者は波を完全に遮ることができる .しかし , 水の循環も遮ることで, 環境污染を招く ことが問題となっている．後者は，波を抑制し，かつ水の循環を妨げず環境負荷を軽減できる利点を持つ. 特に 没水平板は，通常のマウンド・タイプの防波堤や潜堤と異なり柱で支える構造であることから，構造物の下部で も水の循環が可能で, 弚の効果が高い (Yu and Chwang, 1994)(Neelamani and Reddy 1992) . しかし, 波を完全に遮 ることはできない .

No.14-00364 [DOI: 10.1299/transjsme.2014dr0327]

${ }^{* 1}$ 長岡技術科学大学大学院（厂940-2188 新潟県長岡市上富岡町 1603-1)

*2 正員, 長岡技術科学大学工学部

${ }^{* 3}$ 長岡技術科学大学工学部

E-mail of corresponding author: kobayasi@vos.nagaokaut.ac.jp 
構造上，堤防で波を完全に遮ることができない場合もある . 港は船舶の出入りのため，一部を外海に開放せざ るを得ない，外海の波から港内を守り，港内水域の静穏度を高く保つために，港の口をできる限り狭くすること が考えられるが, 港の中に共振による定在波が発生しやすくなることが知られている (椎貝, 1994). この場合, 定 在波を抑制するため港口部の航路を外した位置の水中に潜堤などの波の進入を制限する構造物を設置することが 考えられる.しかし，ある周波数の波が外海から入射しにくいことは, 港内における光の周波数の波が外海へ出 ていきにくいことも意味しており，制御可能な゙波浪条件が固定されてしまう潜堤などでは十分な定在波抑制がで きるとは限らない .

乥こで, 没水平板の一種であり, 波が多樣に変化する状況に応じて板が最適な動作をする水平板を海中に設置 する能動消波機構の導入が考えられる.これまでに，水平板がピッチング運動する能動消波機構の物理モデルに 対して, 水平板に入射する波の反射率 (外乱の抑制率) か導出されており，水平板を静止した場合に比へて反射率 が向上することか理論的に示されている (Yip and Chwang, 1997) . しかし, 外乱が単一周波数で既知の場合が扱わ れており，実際に必要となるフィードバック制御系を構成する方法や実験による検証は行われていない．さらに， 港湾等, 閉水域における波の共振を抑制するためには, 閉水域内の波の動特性を考慮して水平板を動作させ，閉 ループ系の安定性を保証する必要がある . 谷の際, 水平板の動作をピッチング運動に限定する必要はなく, 水平板 を鉛直方向に振動させることも考えられる．

一方，造波機構の用途は，海洋波を再現するための船舶模型の実験水槽 (野原, 1998)(稲垣, 2009)や，水面に任 意の文字やマークを造波するアミューズメント施設 (奥山, 2006)など多岐に及、゙ . 前者の実験水槽には, 主に, ピ ストンタイプやフラップタイプと呼ばれる，壁面に設置された鉛直板が水平方向に駆動するアクチュエータが採 用されている．後者のアミューズメント用途には，三角柱の斜辺部分を鉛直方向に振動させて波を発生させるプ ランジャータイプと呼ばれるアクチュエータが採用されている .これらのアクチュエータは水槽の壁面に設置さ れており，これまでに，壁面から離れた位置にアクチュエータを設置することは検討されていない. 水平板を鉛直 方向に振動させるアクチュエータは壁面から離れた位置に設置することができるため，このようなアクチュエー タを採用すれば，造波機構を設計する自由度が向上することも考えられる．

本論文では, 港湾等, 閉水域における波の共振を抑制することを念頭におき, 鉛直方向に振動する水平板 (鉛直 振動板) を用いた消波機構を有する水槽に対して，低次共振周波数成分の定在波を重点的に抑制するフィードバッ ク制御系を設計し，弚の効果を実験的に検証することを目的とする．

本論文の構成は次の通りである．第 2 章において実験装置の概要を述べる . 未知外乱を抑制する制御系を構成 するため, 第 3 章において, 周波数応答実験に基づきプラントモデルを導出し, 弚の妥当性を検証する. 第 4 章 では， $\mathscr{H}_{\infty}$ 制御系設計を行い，モデル化誤差に対してロバストな制御系を構成する。第 5 章では, 設計した補償器 を実装し，外乱抑制制御実験を行い，外乱抑制効果を検証する．第 6 章で結言を述べる .

\section{2. 実験装置および方法}

本実験装置の概要を図 1 2, 表 1 に示す. 本実験装置は長さ $88 \mathrm{~cm}$ のガラス製の市販品を用いている . 水位セ ンサには, 自作した静電容量式センサを用いている . 具体的には, 長さ約 $1 \mathrm{~m}$ の被覆電線の中央を吸盤で水槽に 固定し，両端を水槽の上部で短絡する . 水槽の奥行方向の水位を平均化して検出するように，これを4 組等間隔 で奥行方向に並べて短絡し，コンデンサの一方の電極とする (図 2 の赤破線の楕円) . リード線がナットで固定さ れた長さ約 $30 \mathrm{~cm}$ のステンレス製ボルトを吸盤で水槽の底に固定し，もう一方の電極 (二つのセンサで共通) とす ることによりコンデンサを形成する .これに交流電圧を印加した際の電流から，静電容量に比例した直流電圧を 出力させる . 二つのセンサの干渉を防ぐため, 静電容量の検出には文献 (土屋, 藤木, 1985) の回路を用いた . 周波 数応答実験結果を境界要素法による解析結果と直接比較できるように, 回路の出力電圧 $(\mathrm{V})$ を定数倍して平衡位 置からの水位变化 $(\mathrm{m})$ に換算したものを各センサの出力信号 $z, y$ とする .ここで定数は, アクチュエータを正弦 波駆動して水槽内に 1 次共振の波が定常的に生じている状態で，各センサ位置における水位の振幅を定規で測り， これを回路の出力電圧の振幅で割ることにより実験的に求めた . アクチュエータにはステッピングモータ内蔵の 電動シリンダを用いる.単純な状況を扱うため, 同一のアクチュエータを左右対称に配置する. 図 1 の左が外乱 用アクチュエータ, 右か制御用アクチュエータである . 外乱および制御アクチュエータの駆動信号は, ステッピン 


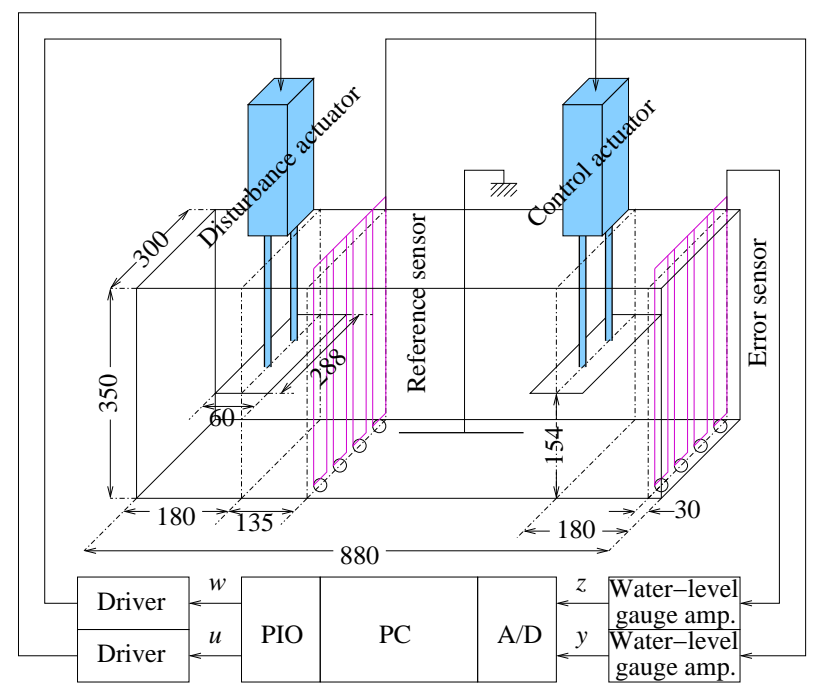

Fig. 1 Block diagram of experimental apparatus

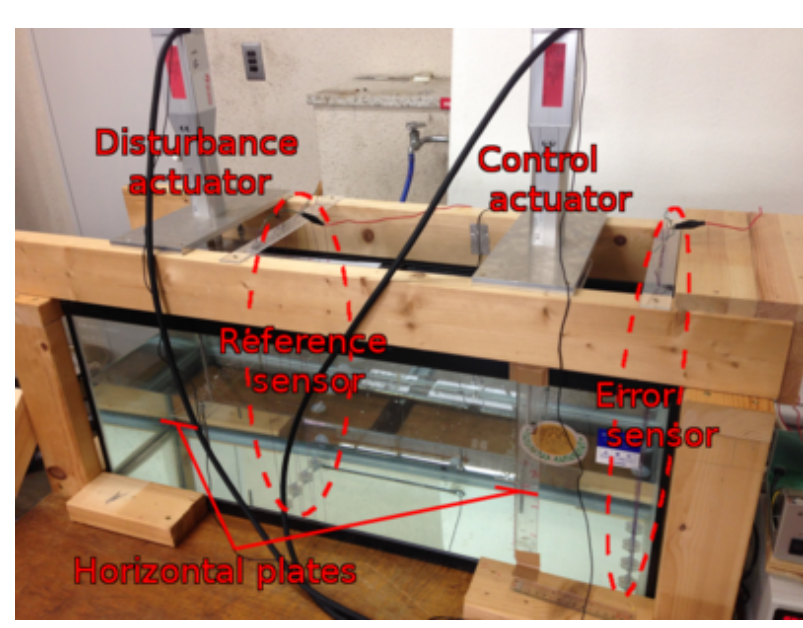

Fig. 2 Photograph of experimental apparatus

Table 1 Experimental equipments

\begin{tabular}{|l|l|}
\hline PC & Dell PowerEdge 840 / Fedora Core 5 (RTAI3.6.1, Linux kernel 2.6.20.21) \\
\hline A/D & Contec AD12-16(PCI) / 12bit, 10 $\mu \mathrm{s}$ \\
\hline PIO & Contec PIO-32/32T(PCI) / 32bit 200ns \\
\hline Actuator & Oriental motor EZC4D005M-A / Thrust70N Speed(max)600mm/s \\
\hline
\end{tabular}

グモータへのパルス信号であり，0.1ms 毎に動作するリアルタイムモジュールにより目標位置に近付くように正/ 逆回転のパルスが生成される.アクチュエータは 1 パルス当たり $0.01 \mathrm{~mm}$ 直進する.以下では, 外乱および制御 アクチュエータの目標位置 $(\mathrm{m})$ を光れ光れ $w, u$ とする . なお, アクチュエータを, 光の平衡位置を中心として振 動させるために, $w, u$ にカットオフ周波数 $0.3 \mathrm{~Hz}$ のハイパスフィルタをかけ，直流成分をカットする .

外乱および制御アクチュエータの駆動信号 $w, u$ からエラーおよびリファレンスセンサの出力信号 $z, y$ までの 2 入力 2 出力のシステムを制御対象とみなして補償器を設計する. 本制御系の目的は, 外乱アクチュエータガ駆動 したときにエラーセンサ $z$ 地点で観測される波を, 制御アクチュエータを駆動してできるだけ小さく抑制するこ とである . 制御アクチュエータの駆動信号 $u$ はリファレンスセンサ $y$ の出力を基に補償器によって生成される .

本実験装置は，港湾内の波の共振をフィードバック制御によって抑制すること念頭に置き構成されている．すな わち，水槽の左端は一部が外海に開かれた港の口であり，外海から入射する波を外乱アクチュエータで模擬する . 右端の壁は岸壁であり，ここに停泊する船舶などに影響を与えないように制御アクチュエータが動作し，定在波を 抑制する .

\section{3. プラントモデルの同定}

補償器設計を行うために, 図 1 の $[w u]^{T}$ から $[z y]^{T}$ までの入出カシステムをプラントと考え, これを $G(s)$ と 表す .ここで, $G_{b a}(s)$ を信号 $a$ から $b$ までの伝達関数とすると，

$$
G(s):=\left[\begin{array}{c}
G_{z w}(s) G_{z u}(s) \\
G_{y w}(s) G_{y u}(s)
\end{array}\right]
$$

である. 本制御対象は基本的に, センサとアクチュエータ間の距離および波の速度によって決まるむだ時間特性 を有する無限次元系であり, 最適な性能を達成する補償器もむだ時間特性を有する無限次元系となると考えられ る.しかし，本論文では，水槽の低次共振周波数成分を重点的に抑制するため，低周波数帯域で十分な精度を有 するプラントモデルを構成し, 弚れに対して有限次元の補償器設計を行うことを考える. とのような補償器設計 は, やはりむだ時間系である能動騒音制御系に対しても行われており，十分な制御性能が得られることが実験に 
基づいて報告されている(例えば(小林, 藤岡, 2005)) . 本論文では周波数応答実験を行い， $G(s)$ に対するノミナル プラント $\bar{G}(s)$

$$
\bar{G}(s):=\left[\begin{array}{cc}
\bar{G}_{z w}(s) & \bar{G}_{z u}(s) \\
\bar{G}_{y w}(s) & \bar{G}_{y u}(s)
\end{array}\right]
$$

を決定する . 周波数特性を境界要素法による数値解析結果と比較することにより，兴の妥当性を検証する．また， 閉ループ系の安定性を保証するために, フィードバックループを構成する伝達関数 $G_{y u}(s)$ のモデル化誤差を見積 もる.

水平板を有する水槽における波の挙動は水平板がない場合に比べて複雑であるため，本制御対象に対して，水 槽のパラメータを陽に含む解析的なモデルを得ることは困難である. 水平板を扱った従来研究においても，弚の ような解析的モデルはこれまでに報告されておらず, 境界要素法などの数值解析がこれまでに行われている . 文 献 (Shin, et al., 2005) では, 有限長の水槽において水平板に不規則波が入射した際の波の時間応答が解析されてい る. 文献 (Yip and Chwang, 1997)(Yu and Chwang, 1994) では, 無限長の水槽において水平板に単一周波数の波が入 射した際の波の反射率と透過率が解析されている.これらの研究において, 水平板の鉛直方向速度を適当に与え れば，鉛直方向に振動する水平板に進行波が入射する場合の解析も行えると考えられる．しかし，本論文で行う ような, 閉水域内の共振を考慮した上で, 水平板の鉛直方向変位からセンサ位置における水位までの周波数応答 の解析を行っている研究は, 筆者らの知る限りこれまでに報告されていない. 乥こで, 弚の解析方法を本論文の 付録に記載する.

\section{$3 \cdot 1$ 周波数応答実験}

まず， $u(t)=0, w(t)=0.005 \sin 2 \pi f t$ として外乱用アクチュエータの鉛直振動板を振幅 $5 \mathrm{~mm}$ で正弦波振動させ， $G_{z w}(s), G_{y w}(s)$ の周波数応答を得る . 次に, $w(t)=0, u(t)=0.005 \sin 2 \pi f t$ として制御用アクチュエータの鉛直振 動板を振幅 $5 \mathrm{~mm}$ で正弦波振動させ， $G_{z u}(s), G_{y u}(s)$ の周波数応答を得る.正弦波信号の周波数 $f$ は $0.5 \mathrm{~Hz}$ から $10 \mathrm{~Hz}$ まで, 対数軸上で等間隔に 260 分割して変化させ , 光れ午れの周波数においてセンサ出力信号 $y(t)$ と $z(t)$ を 記録し, 加振周波数成分 $f$ のフーリエ係数を算出することにより，各伝達関数に対応するゲインと位相を求める.

周波数応答実験によりプラントモデルを正確に同定するために, 時間応答が定常状態に達するまで待つ必要が ある.本実験装置では，1 次共振周波数における定在波が定常状態に到達するまでの時間は，約 50 秒であった . そこで, 周波数応答実験において, 周波数を変化させた後に 55 秒間待ち, 兴の後, センサ出力信号 $y(t)$ と $z(t)$ を 10 周期分記録し，周波数応答の算出に用いた . 周波数応答実験におけるサンプリング周期は $1 \mathrm{~ms}$ とした .

実験結果を 図 3 の青点に示す.また，境界要素法による数値解析の結果を黑の実線に示す . 位相特性の連続的 な変化を見るため, 境界要素法による数值解析では, 図の周波数範囲を等間隔に 2080 分割 (実験の 8 倍) してい る.図より，低周波数域において両者はよく似た特性を示している . 位相特性をみると，アクチュエータとセン サ間の距離が長いほど, 位相遅れが大きくなる傾向がある . (a) $w$ から $z$ までと, (b) $u$ から $z$ までの位相特性を比 べると, 前者の方が位相遅れが大きい .これは, 外乱アクチュエータよりも制御アクチュエータの方が, エラー センサに近い位置に設置されていることに対応している . (c) と (d) も同樣のことがいえる . ただし，3 次共振周 波数以上の周波数帯域において, 数值解析結果のゲイン特性は実験結果よりも大きい.この原因として, 数値解 析では渦の発生を考慮していないのに対し，実験では周波数が高くなるにつれて，水平板の幅よりも波長の短い， 渦を伴った細かな波が生じ，乥れによるエネルギー損失のため波高が小さいことが考えられる．また，(a)の 2 次 共振と 3 次共振の間の反共振周波数以降で, 数値解析結果と実験結果の位相に大きな差が見られるが, この差は 約 360 度であること, 両者の位相が逆方向に変化する周波数におけるゲインが小さい (約 $1.4 \mathrm{~Hz}$ ) か, 隣合うデー 夕点間で位相が 180 度近く変化していること (約 2.6,3.4Hz) から, 実験では観測ノイズを受けて位相か活れれた結 果, 解析結果と逆方向に位相か変化したように表示されたと考えられる . ただし, 両者の複素平面上における挙 動に大きな違いはないことから，両者の周波数応答はよく一致しているといえる .

図 (a) は制御系の開ループ特性を表している. 前述したように，ゲイン特性に共振によるピークか顕著に現れて いることから，外乱信号 $w$ として広帯域信号を入力する場合には，エラーセンサの出力信号にも共振の周波数成 分か顕著に含まれることになる．本論文では，特に 1 4 次共振周波数成分が十分に抑制できるように，次章で補 


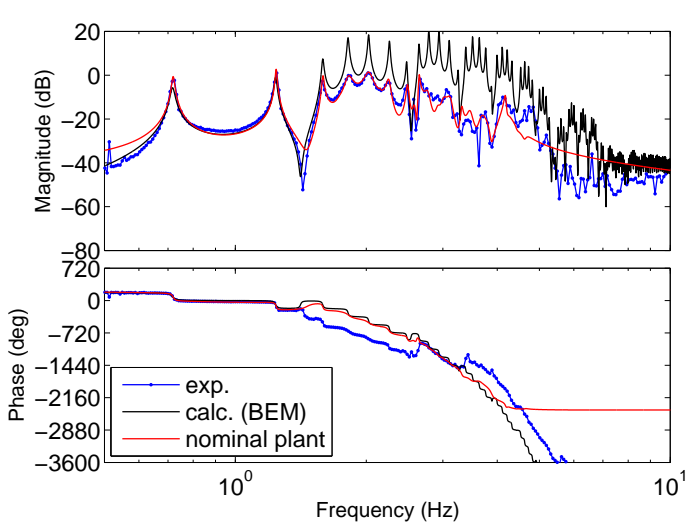

(a) from $w$ to $z$

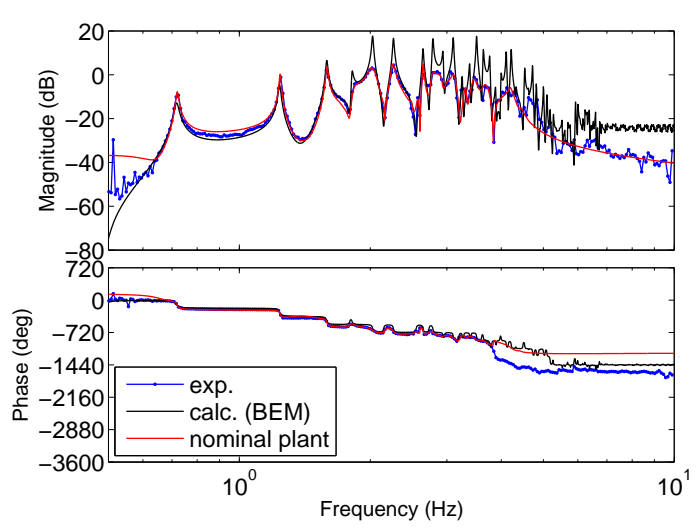

(c) from $w$ to $y$

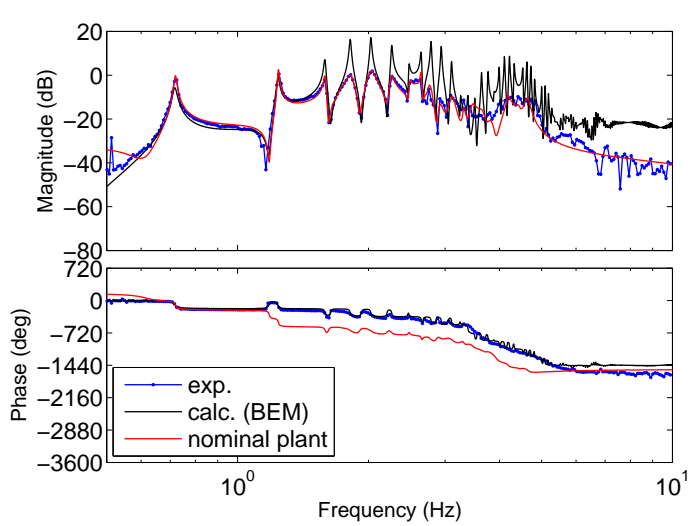

(b) from $u$ to $z$

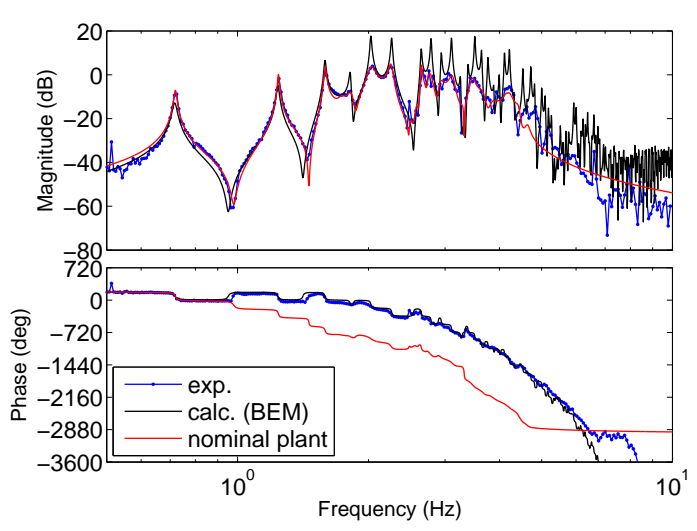

(d) from $u$ to $y$

Fig. 3 Frequency response experiment and nominal plant

償器設計を行う．このために，これらの周波数付近において実験点を精度良く近似するノミナルプラントを得る ことが重要である . また，補償器の次数を抑えるため，ノミナルプラントの次数はできるだけ低いことか望まれ る. 本論文ではノミナルプラントの次数を 50 次とし, 部分空間同定法を用いて周波数応答実験結果を近似するノ ミナルプラントを求めた .ノミナルプラントの周波数応答を図 3 の赤の実線に示す.ただし，数值解析結果と同 樣に, 図の周波数範囲を等間隔に 2080 分割して表示している. 1 4 次共振付近の周波数帯域では, ノミナルプラ ントと実験結果はよく似た傾向を示している．位相特性に見られる差はほぼ 360 度の整数倍であることを確認し ている.よって，このノミナルプラントに基づいて補償器設計を行えば，1 4 次共振付近の周波数帯域で十分な 制御性能を達成する補償器が得られることが期待できる．

\section{$3 \cdot 2$ モデル化誤差の見積もり}

閉ループ系の安定性を確保するために， $G(s)$ を構成する 4 つの伝達関数のうち, 少なくとも $G_{y u}(s)$ のモデル化 誤差を考慮しなくてはならない，本論文では，加法的摂動モデルを用いて $G_{y u}(s)$ を次のように表す:

$$
G_{y u}(s)=\overline{G_{y u}}(s)+W(s) \delta(s)
$$

ここで $W(s)$ は安定な重み関数で, $\delta(s)$ はゲインが 1 以下の安定な伝達関数である . 適当な $\delta(s)$ が存在して式 $(3)$ が成立するように，W(s) を次のように選んだ .

$$
\begin{aligned}
& W(s)=0.05 \cdot \frac{s^{2}+2 \zeta_{1} \omega_{1} s+\omega_{1}^{2}}{\omega_{1}^{2}} \cdot \frac{\omega_{2}^{2}}{s^{2}+2 \zeta_{2} \omega_{2} s+\omega_{2}^{2}} \cdot \frac{\omega_{3}^{2}}{\left(s+\omega_{3}\right)^{2}} \\
& \omega_{1}=2 \pi \times 0.9, \zeta_{1}=0.6, \omega_{2}=2 \pi \times 2.8, \zeta_{2}=0.28, \omega_{3}=2 \pi \times 4
\end{aligned}
$$




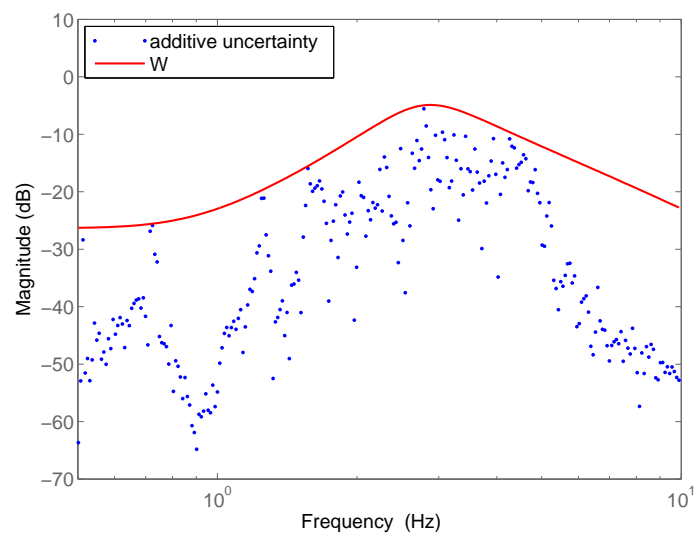

Fig. 4 Additive uncertainty and weight

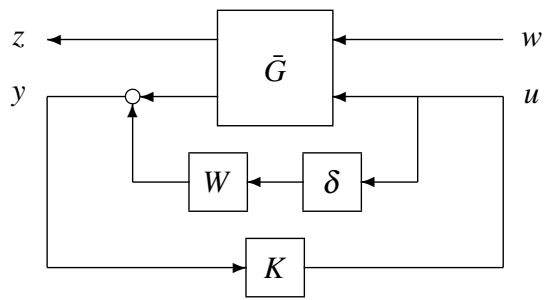

Fig. 5 Closed-loop system

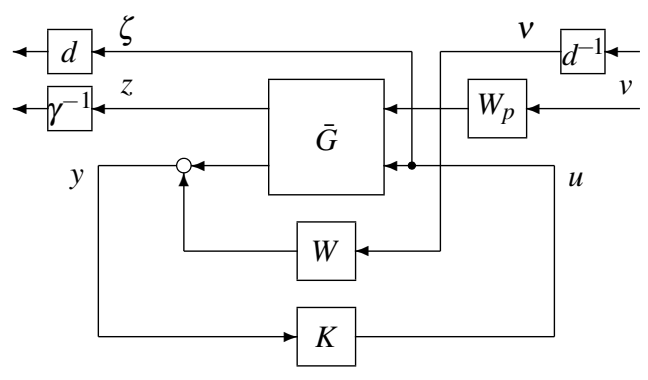

Fig. 6 Robust performance problem with scaling

図 4 に, 加法的モデル化誤差 $G_{y u}(s)-\overline{G_{y u}}(s)$ および重み $W(s)$ のゲイン特性を表す . 低周波数域において良い制 御性能が得られるよう，W(s) のゲインを小さく設定した . 高周波数域では，制御により不要な振動が励起されな いように，W(s)のゲインを大きめに設定した .

\section{4. 補 償器の設 計}

前章のモデル化より，図 1 の閉ループ系は図 5 のように表される .ただし， $K(s)$ は連続時間の補償器である . 本 論文では，次の条件を満足するように $K(s)$ を設計する .

(i) 閉ループ系は任意の $\delta(s)$ に対して内部安定

(ii) $\left\|W_{P}(s) T_{z w}(s)\right\|_{\infty}$ が最小となる

ただし， $T_{z w}(s)$ は $w$ から $z$ までの閉ループ系の伝達関数で, $W_{P}(s)$ は，低周波数域の制御性能を良好にするための 重み関数である.

$$
W_{P}(s)=\frac{\omega_{P}}{s+\omega_{P}}, \quad \omega_{P}=2 \pi \times 1
$$

小ゲイン定理より，上記の設計問題は図 6 の定数スケーリングつき $\mathscr{H}_{\infty}$ 制御問題に帰着できる (細江, 荒木, 1994) . すなわち, 以下の条件下で $\gamma$ を最小化する $K(s)$ を求める問題である:

(i) 図 6 の閉ループ系が内部安定

(ii) 適当な正数 $d$ が存在して閉ループ系の $\mathscr{H}_{\infty}$ ノルムが 1 未満となる

この問題の解 $K(s)$ か浗まったとき，もとの設計問題のノルム $\left\|W_{P}(s) T_{z w}(s)\right\|_{\infty}$ は $\gamma$ 未満となる .

補償器設計には, MATLAB の hinfsyn 関数を用いた . 正数 $d$ に関して , 次のように探索を行った . 各々固定さ れた $d$ に対して，二分法により $\gamma$ の最小化を行い， $\gamma$ を最小化する $d$ と補償器 $K(s)$ を求めた . 光の結果,$d=1.45$ のとき， $\gamma=0.361$ を達成する補償器を得た . 図 7 に $K(s)$ のボード線図を示す. 縦の破線は図 3 の実験で得られ た共振周波数 $f_{1}:=0.724 \mathrm{~Hz}, f_{2}:=1.24 \mathrm{~Hz}, f_{3}:=1.58 \mathrm{~Hz}, f_{4}:=1.82 \mathrm{~Hz}$ を示している. 1 次 , 2 次 , 4 次共振周波数付 近でゲインが極大点を持つこと 3 次共振周波数付近でゲインが極小点を持つことがわかる. 図 3 の周波数応答実 


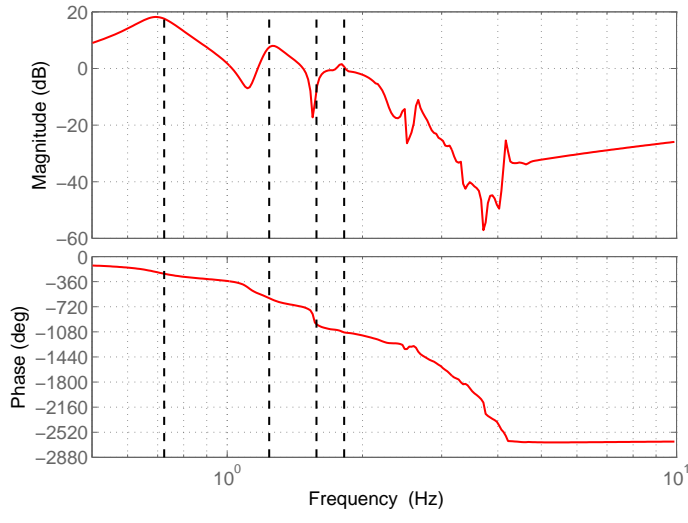

Fig. 7 Bode plot of Controller

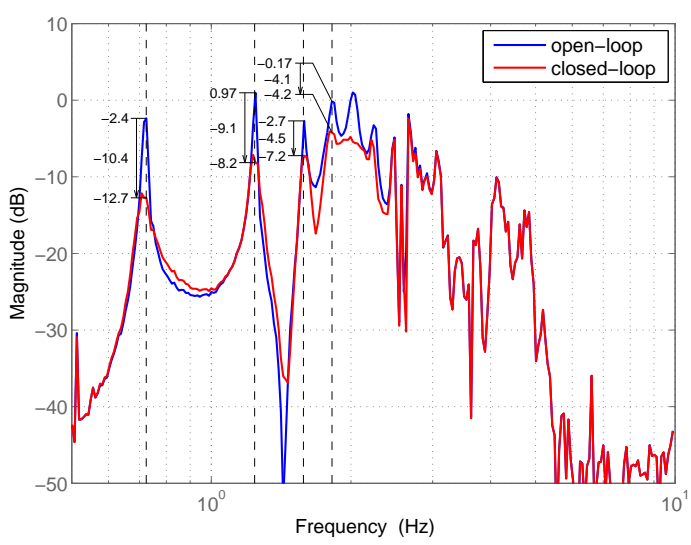

Fig. 8 Open- and closed-loop gain

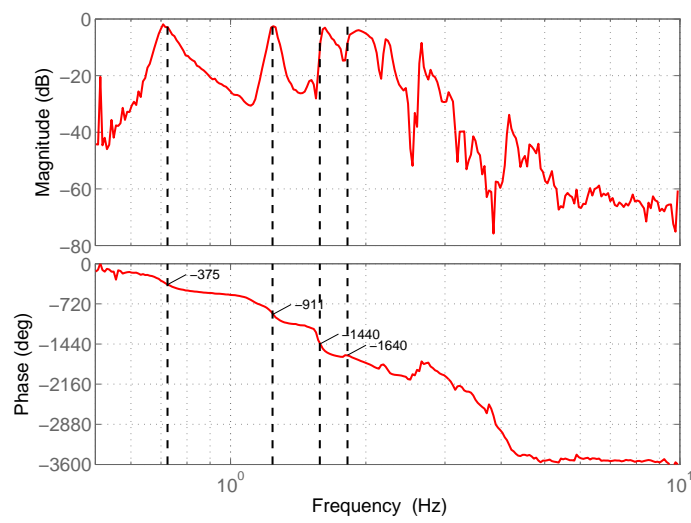

Fig. 9 Bode plot of closed-loop from $w$ to $u$

験結果と図 7 の補償器の特性を用いて算出した閉ループ系のゲイン特性を図 8 の赤の実線に示す. 青い実線は開 ループ特性 (すなわち, 図 3(a) の点と同一)である. 図より, 制御後は制御前に比べて 1 4 次共振周波数成分を关

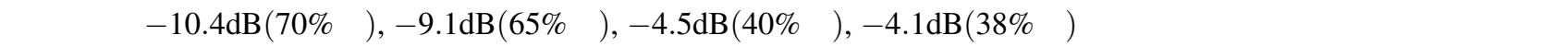
同樣に $w$ から $u$ までの閉ループ特性を図 9 に示す. 1 〜 次共振周波数における位相は 1 次から順に約 -360 度 $(u$ は $w$ と同相), -900 度 (逆相), -1440 度 (同相), -1620 度 (逆相) となっている. またゲインは $0 \mathrm{~dB}$ に近い . この結果 は，本実験装置ではアクチュエータの配置が水槽に対して左右対称であることから，妥当な結果であると言える すなわち, 奇 (偶) 数次の共振周波数においては $u$ を $w$ と同振幅, 同 (逆) 位相の正弦波とすれば, 二つのアクチュ エータが作り出す波は弱め合う.ゲインが $0 \mathrm{~dB}$ よりも若干小くなっている原因は, 実際には波は伝播する距離に より減衰し , エラーセンサに近い制御アクチュエータの方が, より小さな振幅で同程度の振幅の波をエラーセン サの位置において発生できるため, と考えられる .

なお，得られた補償器は，サンプリング周期 $1 \mathrm{~ms}$ て離散化し制御実験に用いた . 離散化には MATLAB の $c 2 d$ 関数を用いた .

\section{5. 外乱抑制制御実験}

まず, 図 8 の閉ループ特性の妥当性を検証するため, 外乱アクチュエータの駆動信号 $w$ として正弦波を入力す る.次に, より現実的な外乱を発生させるため, $w$ としてローパスフィルタを通過させた疑似乱数を入力する.

\section{$5 \cdot 1$ 正弦波外乱抑制制御実験}

正弦波の周波数には, 周波数応答実験結果から得られた 1 4 次までの共振周波数 $f_{1} \sim f_{4}$ を用いる. 正弦波外 乱信号を $w(t)=0.005 \sin 2 \pi f_{i} t$ と与え，外乱用アクチュエータの鉛直振動板を振幅 $5 \mathrm{~mm}$ で正弦波振動させたとき 

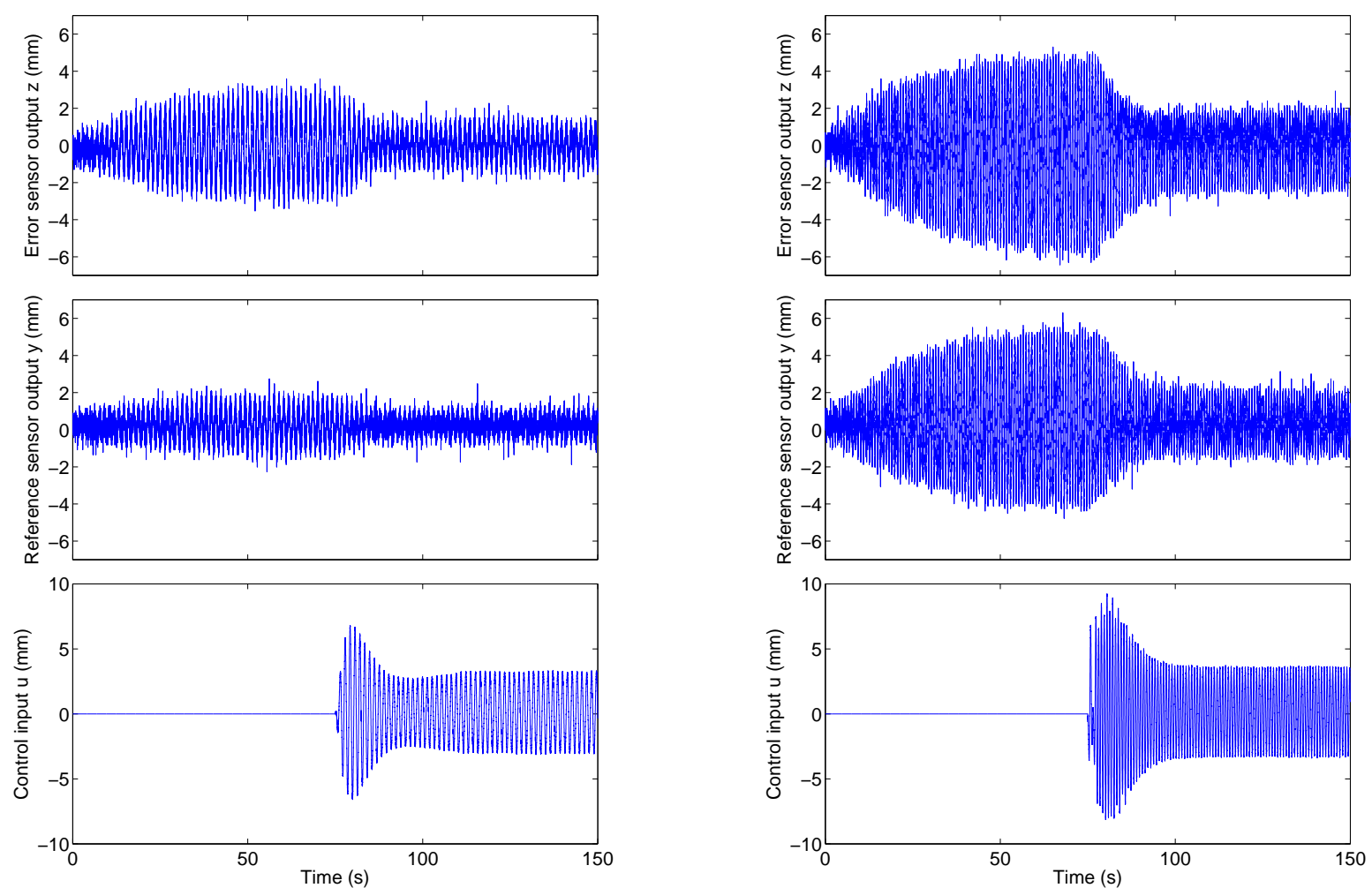

Fig. 10 Time responses for sinusoidal excitation (1st resonance)

Fig. 11 Time responses for sinusoidal excitation (2nd resonance)
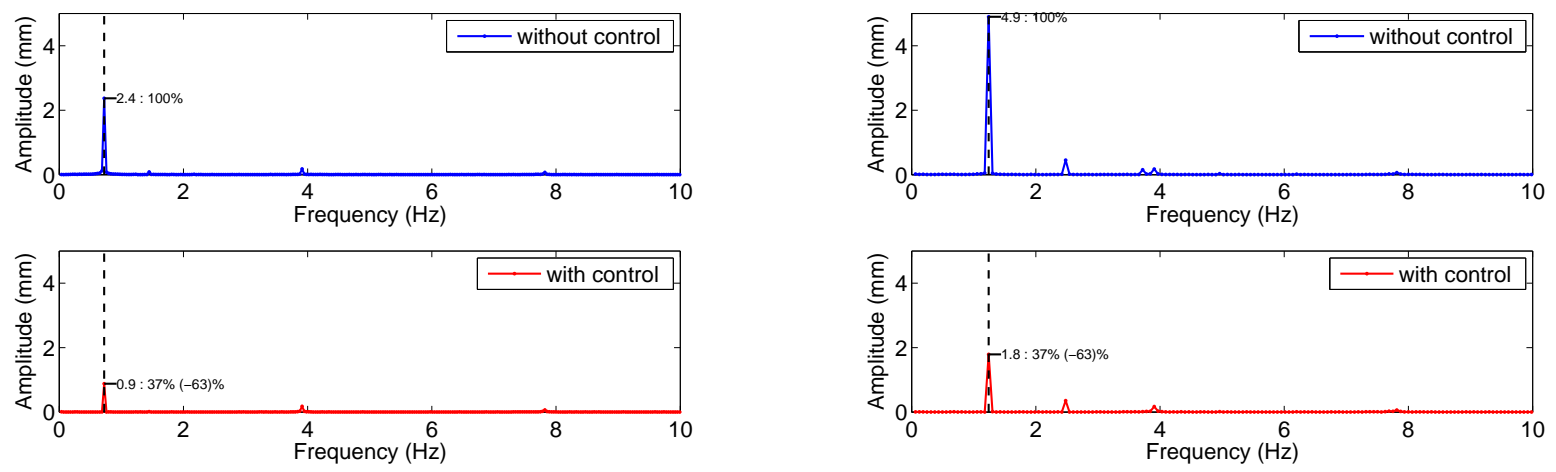

Fig. 12 FFT analysis of $z$ in Fig. 10

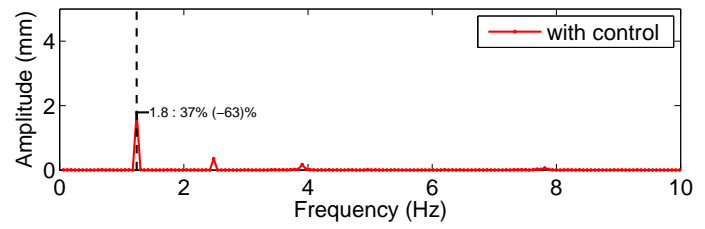

Fig. 13 FFT analysis of $z$ in Fig. 11

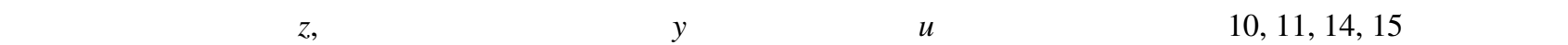
上段, 中段, 下段に示す. 実験時間は 150 秒とし, 実験開始 75 秒経過後に制御を開始している．1 1 4 次共振周波 数いずれの場合も，実験開始後 50 秒程度でエラーセンサにおける水位変化が定常状態に達している.75 秒経過後 に制御開始とともに 20〜30 秒程度で波が抑制されていることがわかる. 制御入力 $u$ の振幅は制御開始直後に一時 的に大きくなり，20〜30 秒程度で定常状態に達している。

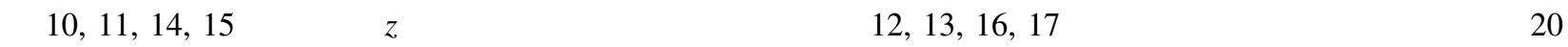
周期分，下段は実験終了直前の 20 周期分を FFT 解析して得られた結果である. 縦の破線は加振周波数を示して いる. 加振周波数成分か顕著であることから，正弦波に近い波が起きていることがわかる. 制御後の加振周波数

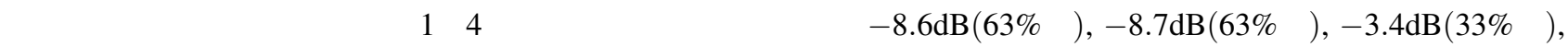
$-4.3 \mathrm{~dB}$ (39\%減)に抑制された .この結果は図 8 の予測とほぼ一致しており，妥当な結果であると考えられる. 

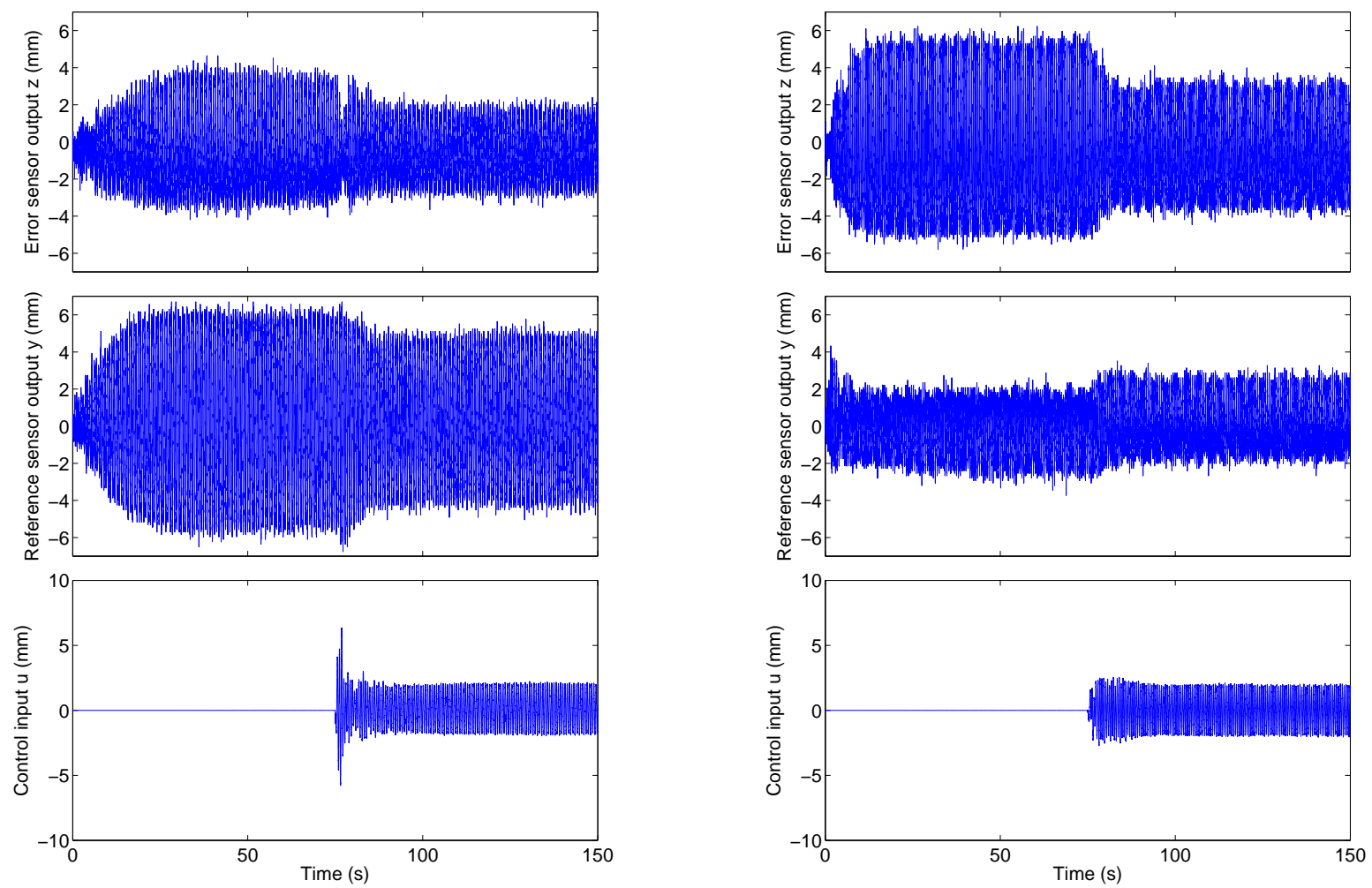

Fig. 14 Time responses for sinusoidal excitation (3rd resonance)

Fig. 15 Time responses for sinusoidal excitation (4th resonance)
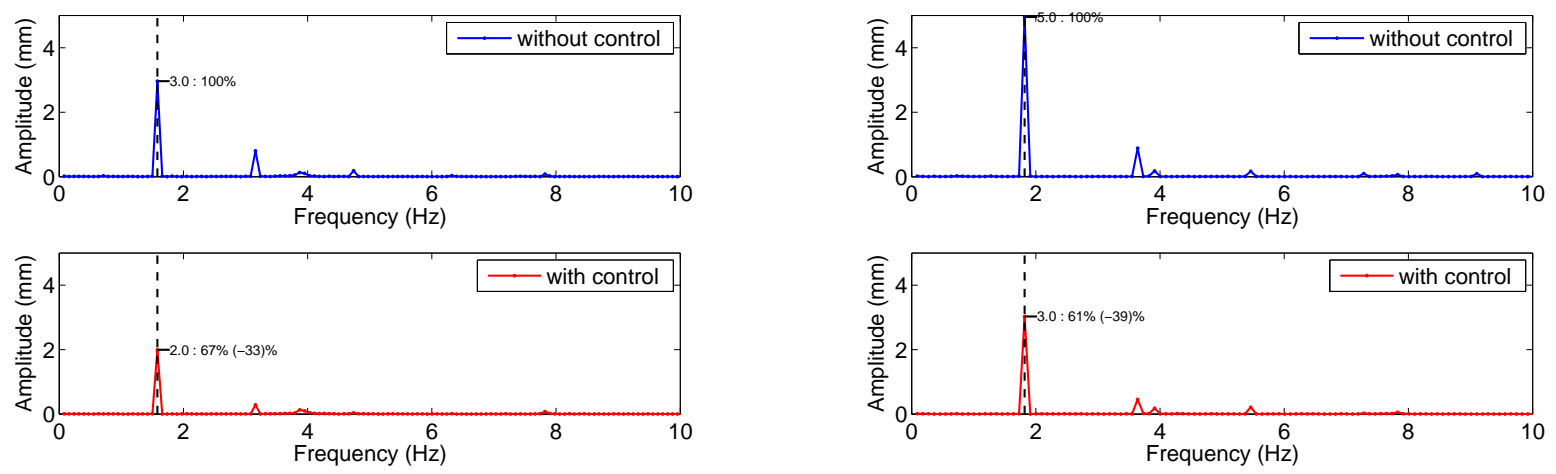

Fig. 16 FFT analysis of $z$ in Fig. 14

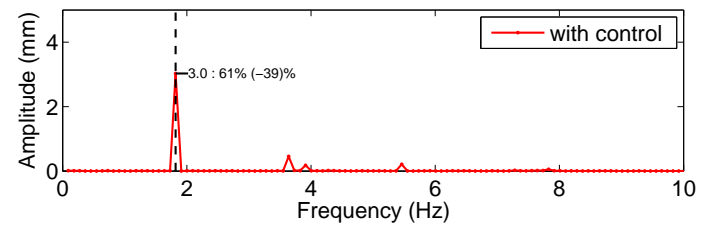

Fig. 17 FFT analysis of $z$ in Fig. 15

\section{$5 \cdot 2$ 広帯域外乱抑制制御実験}

より現実的な外乱を考慮するため, 外乱アクチュエータ駆動信号 $w$ としてカットオフ周波数 $3 \mathrm{~Hz}$ の 1 次ディジタ ルローパスフィルタに疑似乱数を通した信号を入力する.海上の不規則波を扱う従来の研究では, BrestschneiderMitsuyau 型など，比較的狭帯域の周波数スペクトルが仮定される (例えば (Shin, et al., 2005)) . 本節では, より帯 域の広い周波数成分を含む入射波が複数次の共振を同時に励起する厳しい状況を検討するため, 上記のように信 号 $w$ を与え .

制御なし $(u \equiv 0)$ の場合のエラーセンサ出力 $z$, リファレンスセンサ出力 $y$, 外乱入力 $w$ の時間応答波形を図 18 の 弚れ光れ上段, 中段, 下段に示す. また，制御ありの場合の $z, y$, および制御入力 $u$ を図 19 の光れ光れ上段，中段， 下段に示す. 外乱入力 $w$ は制御なしの場合と同一である . 図より，末知外乱に対しても，本制御系の安定性が保 たれていることが分かる.$z$ の最大值と最小值を横破線に示す．この変化幅は $12.5 \mathrm{~mm}($ 制御なし)，9.9mm (制御あ り)となり，フィードバック制御により約 $21 \%$ の抑制効果が得られた ・また， RMS 值を求めた結果，926(制御な し）, 791 (制御あり) となり，約 $15 \%$ の抑制効果が得られた . 


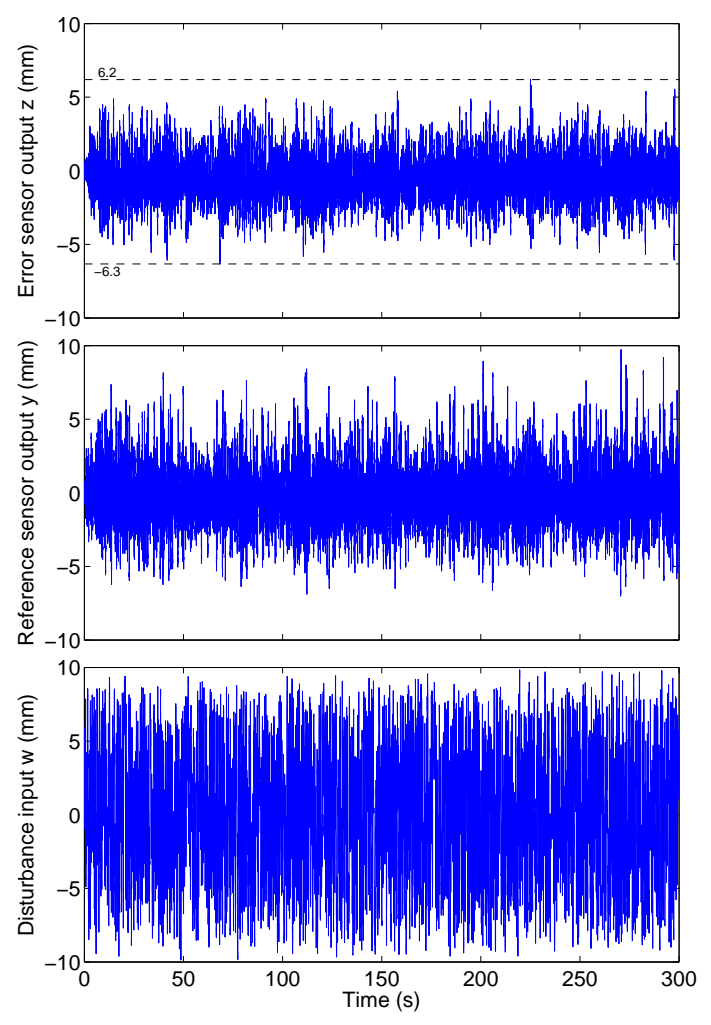

Fig. 18 Time responses for wide range excitation (without control)

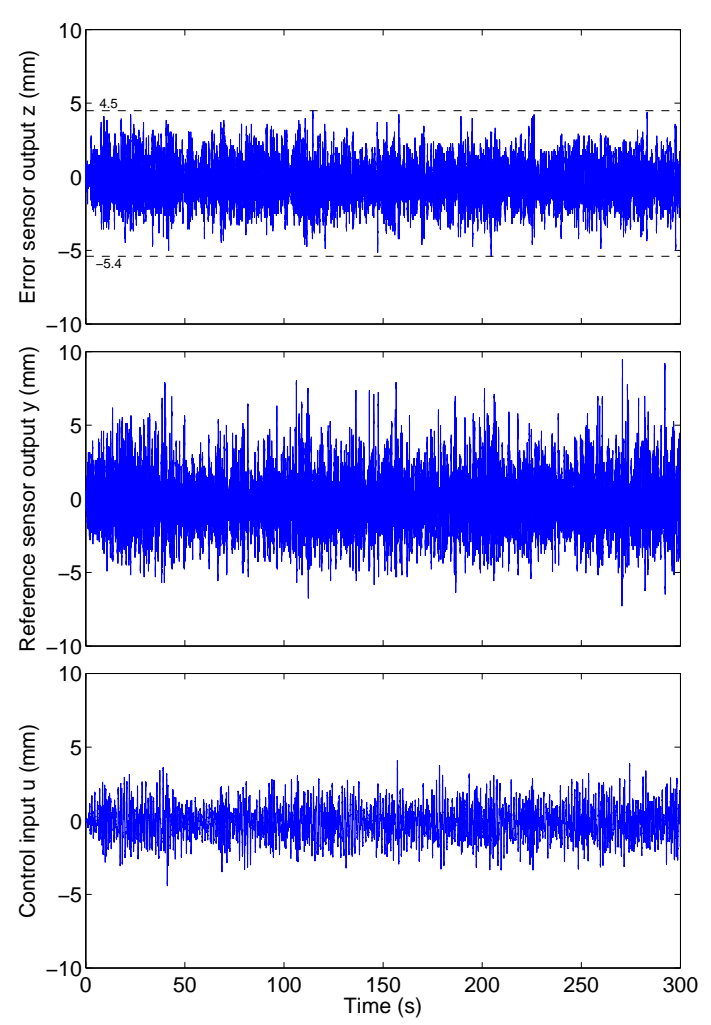

Fig. 19 Time responses for wide range excitation (with control)
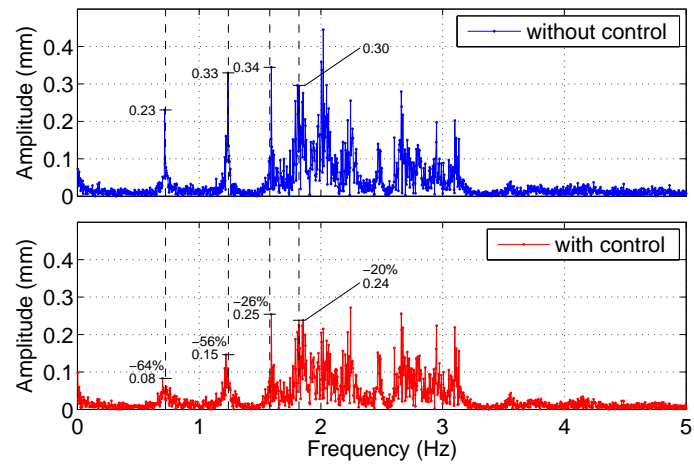

Fig. 20 FFT analysis of $z$ in Figs. 18 and 19

図 18, 19 における $z$ の振幅スペクトルを図 20 に示す. 縦の破線は 1 ～4 次共振周波数成分を示している. 約 $2 \mathrm{~Hz}$ 以下の周波数帯域で, フィードバック制御により共振周波数成分の振幅が低減されていることがわかる．1 4 次 共振周波数成分の振幅は，制御なしの場合に比べて光れ光れ約 64\%, 56\%, 26\%,20\% 抑制された 1 次，2 次成分 が3 次，4 次成分より顕著に低減されており，正弦波外乱の抑制実験結果とともに図 8 の予測に整合する，妥当な 結果であるといえる。

\section{6. 結 言}

本論文では，鉛直方向に振動する水平板を用いた消波機構を提案し，弚の外乱抑制性能を実験的に検証した． 未知外乱を抑制する制御系を構成するために，周波数応答実験に基づきプラントモデルを同定し，能制御を用 いて，モデル化誤差に対してロバストな制御系を設計した . 外乱抑制制御実験を行い，以下の知見を得た . 正弦 波外乱の場合，1〜4 次共振周波数において，3〜6 割の抑制効果が得られた . 広帯域外乱の場合，時間応答波形に

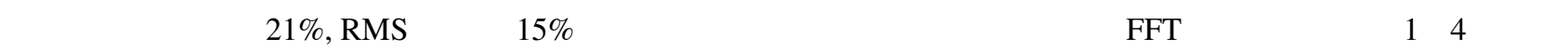


周波数成分において 2〜6 割の抑制効果が得られた .これらの外乱抑制効果は制御系設計時の閉ループ特性と整合 しており，妥当な実験結果であると言える．

以上より，鉛直方向に振動する水平板を用いた消波機構とフィードバック制御に基づいて水槽内の定在波を抑制 する制御系を構成し，未知外乱に対する抑制効果が得られることを実験的に示した．実際の港において周波数応 答実験を行うことは非現実的であるため, 今後，数值解析モデルの精度を高め，解析結果に基づいて補償器設計 を行うことが課題として挙げられる.

謝 辞

最後に，本論文を執筆するにあたり貴重な御意見・御指摘をいただいた長岡技術科学大学名誉教授 白樫正高先 生に深く感謝いたします。

\section{付録 A. 解析モデル}

水槽中の波の挙動は奥行き方向に一樣であると仮定し，奥行き方向の自由度を無視した二次元の水槽における 波の挙動を考える (図 21). 水槽の水平右向きに $x$ 軸，鉛直上向きに $z$ 軸をとり，水槽の左端，水面上に原点をと る $. x=0, L$ の位置に垂直の壁が設置されているとする . 水槽は $z=-H$ の位置に水平の底面を持つとする.$x$ 方 向の長さ $L_{p}, z$ 方向の高さ $H_{p}$ の水平板が二枚，水中に設置されているとする.ただし，水平板の左下端の $z$ 座標

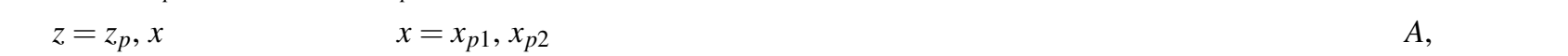
$\omega$ の正弦波振動を行うものとし，右側の水平板は静止しているとする .

流体運動を非粘性・非圧縮・渦なしと仮定すると，速度ポテンシャル $\Phi(x, z, t)$ が存在し，任意の時刻 $t$ におい て次式が成り立つ.

$$
\frac{\partial^{2} \Phi}{\partial x^{2}}+\frac{\partial^{2} \Phi}{\partial z^{2}}=0
$$

波の波高は十分小さく表面張力を無視できるとすると，自由表面において次式が成り立つ．

$$
\frac{\partial^{2} \Phi}{\partial t^{2}}+\alpha \frac{\partial \Phi}{\partial t}+g \frac{\partial \Phi}{\partial z}=0 \quad(z=0)
$$

ただし,$g$ は重力加速度である.$\alpha$ はエネルギー散逸を考慮するための正数である ${ }^{1}$. 水槽の底および壁面で次式 が成り立つ。

$$
\frac{\partial \Phi}{\partial z}=0 \quad(z=-H), \quad \frac{\partial \Phi}{\partial x}=0 \quad(x=0, L)
$$

右側の水平板は静止しているため, 光の周囲における法線方向速度は 0 となる .よって次式が成り立つ.

$$
\frac{\partial \Phi}{\partial z}=0 \quad\left(x \in\left[x_{p 2}, x_{p 2}+L_{p}\right], z=z_{p}, z_{p}+H_{p}\right), \quad \frac{\partial \Phi}{\partial x}=0 \quad\left(z \in\left[z_{p}, z_{p}+H_{p}\right], x=x_{p 2}, x_{p 2}+L_{p}\right)
$$

一方左側の水平板は前述のように $z$ 方向に振動しており, 弚の $z$ 方向変位 $\Delta z_{p}(t)$ が

$$
\Delta z_{p}(t)=\operatorname{Re}\left\{A e^{j \omega t}\right\}
$$

と与えられるとする .このとき, 水平板の上下面における速度ポテンシャルの $z$ 方向の微係数は, 水平板の速度に 一致しなくてはならない.よって，次式が成り立つ．

$$
\frac{\partial \Phi}{\partial z}=\frac{d}{d t} \Delta z_{p}(t)=\operatorname{Re}\left\{j \omega A e^{j \omega t}\right\} \quad\left(x \in\left[x_{p 1}, x_{p 1}+L_{p}\right], z=z_{p}, z_{p}+H_{p}\right)
$$

ただし，水平板の鉛直方向の振動は，水平板側面における $x$ 方向速度に影響を与えないとし，右側の水平板と同 樣に次のように仮定する .

$$
\frac{\partial \Phi}{\partial x}=0 \quad\left(z \in\left[z_{p}, z_{p}+H_{p}\right], x=x_{p 1}, x_{p 1}+L_{p}\right)
$$

\footnotetext{
1従来研究では $\alpha=0$ の式が仮定されるが, これを仮定して後述する手順で数值解析を行うと， $\phi(x, z)$ と光の法線方向の傾きか純虚数の範囲 で求まる. 产の結果, 周波数応答関数式 (15) の位相は 0 か 180 度の二值のみとなり, 実験結果に見られるような位相の連続的な変化を考察 することができない．また，エネルギ一散逸を考慮しないため，共振周波数におけるピークゲインが過大となる． $\alpha$ を正数とおくことにより， 図 3 に示したように，実験結果に近い位相特性が得られる．また，共振周波数におけるピークゲインも低くなる．
} 


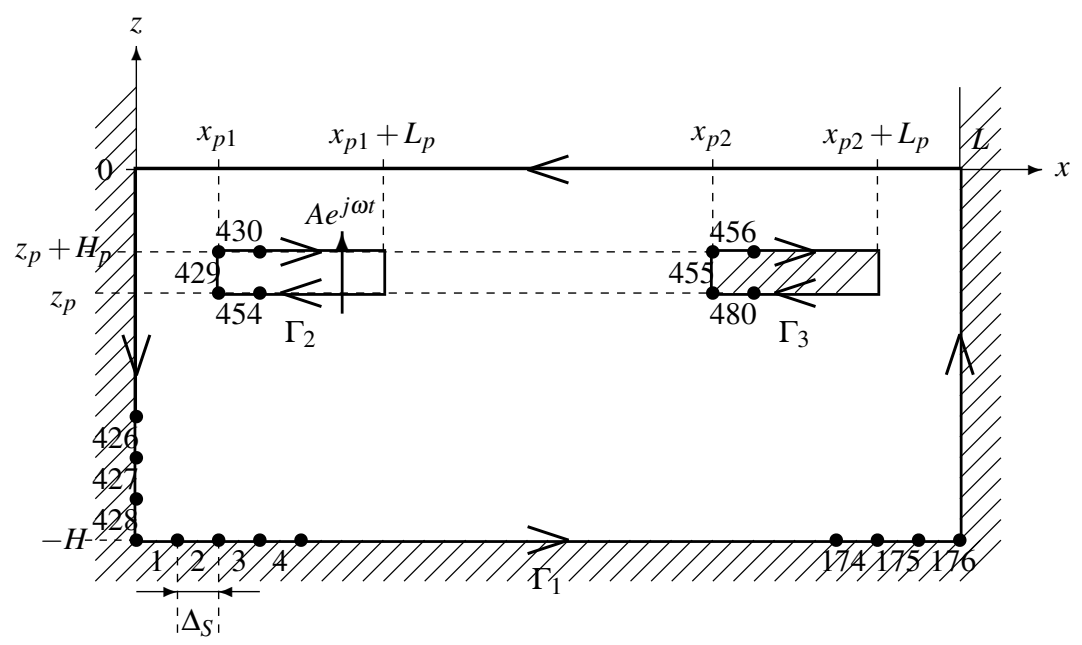

Fig. 21 Numerical model for boundary element method

システムの周波数応答，すなわち水平板をある周波数で振動させた場合の水面の定常的な挙動を導出するため， 調和振動を仮定して速度ポテンシャルを次のようにおく．

$$
\Phi(x, z, t)=\operatorname{Re}\left\{\phi(x, z) e^{j \omega t}\right\}
$$

また，位置 $x$ における水面の $z$ 方向変位も正弦波振動解

$$
\eta(x, t)=\operatorname{Re}\left\{B e^{j \omega t}\right\}
$$

を仮定する . ただし $B$ は未知の複素数である .このとき水面において次式が成り立つ .

$$
\frac{\partial \Phi}{\partial z}=\frac{d \eta}{d t} \Leftrightarrow \frac{\partial \phi}{\partial z}=j \omega B \Leftrightarrow B=\frac{1}{j \omega} \frac{\partial \phi}{\partial z}
$$

よって, 水平板の $z$ 方向変位から, 位置 $x$ における水面の $z$ 方向変位までの周波数応答関数を $G(x, j \omega)$ と定義す ると, これは次式で与えられる．

$$
G(x, j \omega):=\frac{B e^{j \omega t}}{A e^{\omega t}}=\frac{1}{j \omega A} \frac{\partial \phi(x, 0)}{\partial z}
$$

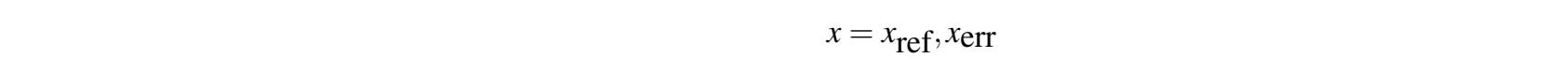
ファレンスセンサまでの周波数応答関数 $G_{y w}(j \omega)$, 外乱用アクチュエータからエラーセンサまでの周波数応答関数 $G_{z w}(j \omega)$ は， $G(x, j \omega)$ を用いて光れ次式で与えられる .

$$
G_{y w}(j \omega):=G\left(x_{\mathrm{ref}}, j \omega\right), \quad G_{z w}(j \omega):=G\left(x_{\mathrm{err}}, j \omega\right)
$$

また，実験装置が左右対称であることから，制御用アクチュエータからリファレンスセンサまでの周波数応答関 数 $G_{y u}(j \omega)$, 制御用アクチュエータからエラーセンサまでの周波数応答関数 $G_{z u}(j \omega)$ も同樣に, $G(x, j \omega)$ を用いて 㫕れ光れ次式で与えられる。

$$
G_{y u}(j \omega):=G\left(L-x_{\mathrm{ref}}, j \omega\right), \quad G_{z u}(j \omega):=G\left(L-x_{\mathrm{err}}, j \omega\right)
$$

よって以降では, 上記 4 つの周波数応答関数を求めるために, $\frac{\partial \phi(x, 0)}{\partial z}$ を数值的に求めることを考える.

式 (12) を式 $(5) \sim(11)$ に代入し, 時間項 $e^{j \omega t}$ を消去すると, 複素関数 $\phi(x, z)$ は次式を満足しなくてはな らない.

$$
\frac{\partial^{2} \phi}{\partial x^{2}}+\frac{\partial^{2} \phi}{\partial z^{2}}=0
$$




$$
\begin{aligned}
& \left(-\omega^{2}+j \omega \alpha\right) \phi+g \frac{\partial \phi}{\partial z}=0 \quad(z=0) \\
& \frac{\partial \phi}{\partial z}=0 \quad(z=-H), \quad \frac{\partial \phi}{\partial x}=0 \quad(x=0, L), \quad \frac{\partial \phi}{\partial z}=0 \quad\left(x \in\left[x_{p 2}, x_{p 2}+L_{p}\right], z=z_{p}, z_{p}+H_{p}\right) \\
& \frac{\partial \phi}{\partial x}=0 \quad\left(z \in\left[z_{p}, z_{p}+H_{p}\right], x=x_{p 1}, x_{p 1}+L_{p}, x_{p 2}, x_{p 2}+L_{p}\right), \quad \frac{\partial \phi}{\partial z}=j \omega A \quad\left(x \in\left[x_{p 1}, x_{p 1}+L_{p}\right], z=z_{p}, z_{p}+H_{p}\right)
\end{aligned}
$$

式（12）のように正弦波振動解を仮定したことによって，水面における境界条件式（6）が式（19）のように時刻 $t$ に依存しなくなるため, 時間応答を経由せずに周波数応答を直接求めることができる .

\section{付録 B．境界要素法による数值解析}

実験装置に合わせて , パラメータを次のようにおく: $L=0.88, H=0.19, x_{p 1}=0.15, x_{p 2}=0.67, L_{p}=0.06, z_{p}=0.15$, $H_{p}=0.005$. 境界要素として一定要素 (直線要素で, 中央に節点を有し, 要素内の関数値は一定) を用い, 弚の長さ はすべての要素共通で $\Delta_{S}:=0.005$ とする.このため水深は, 実験装置の 0.192 を 0.19 に近似する . また, 水平板 の高さも実験装置の $3 \mathrm{~mm}$ を $5 \mathrm{~mm}$ に近似する. 水槽の水平方向の要素分割数を $N_{L}:=L / \Delta_{S}=176$, 鉛直方向の要 素分割数を $N_{H}:=H / \Delta_{S}=38$ とする. 水平板の水平方向の要素分割数を $N_{P}:=L_{P} / \Delta_{S}=12$ とする. また $\alpha=0.1$ とする .

以下では，一定要素を用いて前述の問題を連立一次方程式で近似する手順を示す . この手順は文献 (戶川, 下関, 1983) と同一であるため, 以降では結果のみを示す . ラプラス方程式 (18) の解は, 境界積分方程式を満足するこ

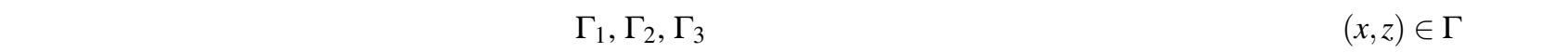
て次式が成り立つ。

$$
\phi(x, z)=\frac{1}{\pi} \int_{\Gamma}\left\{\left(\log \frac{1}{r}\right) \frac{\partial \phi(\xi, \eta)}{\partial n}-\phi(\xi, \eta) \frac{\partial}{\partial n}\left(\log \frac{1}{r}\right)\right\} d s
$$

ここで, $\Gamma:=\Gamma_{1}+\Gamma_{2}+\Gamma_{3}, r:=\sqrt{(\xi-x)^{2}+(\eta-z)^{2}}$ で, $(\xi, \eta) \in \Gamma$ は積分経路上の座標である. 長さ $\Delta_{S}$ の一定 要素を用いて境界を分割すると， $\Gamma_{1}, \Gamma_{2}, \Gamma_{3}$ の要素分割数は光れ光れ $N_{1}:=2\left(N_{L}+N_{H}\right)=428, N_{2}:=2 N_{p}+2=26$, $N_{3}:=2 N_{p}+2=26$ となり，全境界要素数は $N:=480$ となる . 各要素の節点を境界要素の中間にとり，節点の座標 を $\left(x_{i}, z_{i}\right)$ とすると，式 $(22)$ は次のように近似的に離散化される .

$$
\frac{1}{2} \phi_{i}=\sum_{j=1}^{N}\left\{h_{i j}^{\prime} \phi_{j}+g_{i j} \bar{\phi}_{j}\right\}, \quad h_{i j}^{\prime}:=-\frac{1}{2 \pi} \int_{C_{j}} \frac{\partial}{\partial n}\left(\log \frac{1}{r_{i j}}\right) d s, \quad g_{i j}:=\frac{1}{2 \pi} \int_{C_{j}} \log \frac{1}{r_{i j}} d s
$$

ただし, $\phi_{j}, \bar{\phi}_{j}$ は乥れ艺れ, $j$ 番目の一定要素 $C_{j}$ における $\phi$ の值，弚の法線方向微係数である.$r_{i j}$ は, $i$ 番目の 一定要素における節点 $\left(x_{i}, z_{i}\right)$ と, $C_{j}$ 上の座標 $(\xi, \eta) \in C_{j}$ 間の距離で, $r_{i j}:=\sqrt{\left(\xi-x_{i}\right)^{2}+\left(\eta-z_{i}\right)^{2}}$ である $. i=j$ の場合 , 係数 $h_{i j}^{\prime}, g_{i j}$ は次のように与えられる.

$$
h_{i i}^{\prime}=0, \quad g_{i i}=\frac{L_{i}}{2 \pi}\left(1+\log \frac{2}{L_{i}}\right)
$$

ただし,$L_{i}$ は一定要素 $C_{i}$ の長さである.一方,$i \neq j$ の場合, ガウスの 3 点積分公式

$$
\int_{-1}^{1} f(\xi) d \xi \simeq \sum_{k=1}^{3} w_{k} f\left(\xi_{k}\right), \quad w_{1}:=\frac{5}{9}, \quad w_{2}:=\frac{8}{9}, \quad w_{3}:=\frac{5}{9}, \quad \xi_{1}:=-\sqrt{\frac{3}{5}}, \quad \xi_{2}:=0, \quad \xi_{3}:=\sqrt{\frac{3}{5}}
$$

を用いると係数 $h_{i j}^{\prime}, g_{i j}$ の近似值が次のように与えられる .

$$
h_{i j}^{\prime}=\frac{d_{i j} L_{j}}{4 \pi} \sum_{k=1}^{3} \frac{w_{k}}{r_{i k}^{2}}, \quad g_{i j}=\frac{L_{j}}{4 \pi} \sum_{k=1}^{3}\left(w_{k} \log \frac{1}{r_{i k}}\right)
$$

ここで $r_{i k}$ は, $i$ 番目の節点 $\left(x_{i}, z_{i}\right)$ と, 3 点積分公式により $C_{j}$ 上に定められた 3 点 $\left(x_{k}, z_{k}\right)(k=1,2,3)$ の距離で,

$$
r_{i k}:=\sqrt{\left(x_{k}-x_{i}\right)^{2}+\left(z_{k}-z_{i}\right)^{2}}, \quad x_{k}:=x_{j}+\frac{L_{j}}{2} \cos \left(\theta_{j}\right) \cdot \xi_{k}, \quad z_{k}:=z_{j}+\frac{L_{j}}{2} \sin \left(\theta_{j}\right) \cdot \xi_{k}
$$


である .ただし,$\theta_{j}$ は, $C_{j}$ 要素が $x$ 軸となす角である.$d_{i j}$ は, $C_{j}$ 要素を通る直線に対して , 節点 $M_{i}$ から下ろし た垂線の長さで, $d_{i j}=\left(x_{j}-x_{i}\right) \sin \theta_{j}-\left(z_{j}-z_{i}\right) \cos \theta_{j}$ である.

$$
\begin{aligned}
& u=\left[\phi_{1} \phi_{2} \cdots \phi_{N}\right]^{T}, q=\left[\bar{\phi}_{1} \bar{\phi}_{2} \cdots \bar{\phi}_{N}\right]^{T} \text { とおくと, 式 (23) は次のように書ける. } \\
& \Pi u=\Xi q
\end{aligned}
$$

ただし $, \Pi:=\frac{1}{2} I-\Pi^{\prime}$ で, $\Pi^{\prime}, \Xi$ は光れ光れ,$(i, j)$ 要素が $h_{i j}^{\prime}, g_{i j}$ で与えられる正方行列である .ベクトル $q$ は次 のように与えられる .

$$
q^{T}=\left[\begin{array}{lll:llll:l}
0_{\left(N_{L}+N_{H}\right) \times 1}^{T} & q_{s}^{T} & 0_{N_{H} \times 1}^{T} & 0 & j \omega A 1_{N_{P} \times 1}^{T} & 0 & -j \omega A 1_{N_{P} \times 1}^{T} & 0_{2\left(1+N_{P}\right) \times 1}^{T}
\end{array}\right]^{T}
$$

破線で分けられた三つの部分は左から，水槽の周囲，左側のプレート，右側のプレートの境界条件に対応する． $0_{n \times 1}, 1_{n \times 1}$ は乥れ光れ, $n$ 行 1 列で要素がすべて 0 または 1 のべクトルである.$q_{s}$ は水面の節点における法線方向 微係数 $\frac{\partial \phi(x, 0)}{\partial z}$ で, 求めるべき未知べクトルである.式 (19) より， $q_{s}$ は $u$ の成分を用いて次式で与えられる.

$$
q_{s}=\frac{\omega^{2}}{g} u\left(N_{L}+N_{H}+1: N_{L}+N_{H}+N_{L}, 1\right)
$$

ただし,$u(n: m, 1)(n<m)$ は, 列ベクトル $u$ のうち第 $n$ 行から第 $m$ 行までを取り出したベクトルを表す. 式 $(28)$ において,$u$ の成分を左辺に移項すると次式を得る .

$$
\left(\Pi-\frac{\omega^{2}}{g} \Xi\left(:, N_{L}+N_{H}+1: N_{L}+N_{H}+N_{L}\right)\right) u=\Xi\left(:, 2\left(N_{L}+N_{H}\right)+1: 2\left(N_{L}+N_{H}\right)+2\left(1+N_{P}\right)\right)\left[\begin{array}{c}
0 \\
j \omega A 1_{N_{P} \times 1} \\
0 \\
j \omega A 1_{N_{P} \times 1}
\end{array}\right]
$$

ただし,$\Xi(:, n: m)(n<m)$ は, 行列 $の$ の第 $n$ 列から第 $m$ 列までを取り出した行列を表す . 上式に左から , 上 式左辺の括弧内の行列の逆行列をかければ, $u$ が求まり，次いで式（30)により $q_{s}$ が求まる.

$$
\text { 文献 }
$$

細江繁幸, 荒木光彦, 制御系設計 $-H_{\infty}$ 制御と光の応用 - (1994), 朝倉書店.

稲垣聡, 水を摇らす一造波装置を用いた水理実験一, 日本機械学会誌, Vol.112, No.1090 (2009), pp.32-33.

小林泰秀, 藤岡久也, サンプル値 $\mathscr{H}_{\infty}$ 制御に基づく一次元ダク卜系の消音制御, 日本機械学会論文集 C 編, Vol.71,

No.710 (2005), pp.2953-2960.

Neelamani, S. and Reddy, M. S., Wave transmission and reflection characteristics of a rigid surface and submerged horizontal plate, Ocean Engineering, Vol.19, No.4 (1992), pp.327-341.

野原勉, 波の計測と制御一太平洋の波を造る一, 計測と制御, Vol.37, No.5 (1998), pp.341-348.

奥山悦郎, 分割型吸収式造波機を用いて水面に波で文字を描く技術, 三井造船技報, No.188 (2006), pp.15-20.

椎貝博美, 流体力学ノート 9. 紙風船と港と寺田寅彦, ながれ, Vol.13, No.6 (1994), pp.479-482.

Shin, R. S., Chou, C.-r. and Yim, J. Z., Numerical estimations of wave reflection coefficients for irregular waves over submerged obstacles, Proceedings of the 50th International Offshore and Polar Engineering Conference, Seoul, Korea (2005), pp.40-47.

戶川隼人, 下関正義, パソコンによる境界要素法入門 (1983), サイエンス社.

土屋義人, 藤木繁男, 容量式波高計の改良と現地観測への適用, 京都大学防災研究所年報, Vol.B-2, No.28 (1985), pp.549-564.

Yip, T. L. and Chwang, A. T., Water wave control by a pitching plate, ASCE Journal of Engineering Mechanics, Vol.123, No.8 (1997), pp.800-807.

Yu, X. and Chwang, A. T., Water waves above submerged porous plate, ASCE Journal of Engineering Mechanics, Vol.120, No.6 (1994), pp.1270-1282. 


\section{References}

Hosoe, S. and Araki, M., Design of control systems $-H_{\infty}$ control and its applications - (1994), Asakura Publishing Co., Ltd (in Japanese).

Inagaki, S., Hydraulic model tests performed with wave maker, Journal of the Japan Society of Mechanical Engineers, Vol.112, No.1090 (2009), pp.32-33 (in Japanese).

Kobayashi, Y. and Fujioka, H., Active noise control of one-dimensional duct via sampled-data $\mathscr{H}_{\infty}$ control, Transactions of the Japan Society of Mechanical Engineers, Series C, Vol.71, No.710 (2005), pp.2953-2960 (in Japanese).

Neelamani, S. and Reddy, M. S., Wave transmission and reflection characteristics of a rigid surface and submerged horizontal plate, Ocean Engineering, Vol.19, No.4 (1992), pp.327-341.

Nohara, T., Generation of ocean waves, Journal of the Society of Instrument and Control Engineers, Vol.37, No.5 (1998), pp.341-348 (in Japanese).

Okuyama, E., Technology for drawing letters on water surface by element absorbing wave maker, MITSUI ZOSEN TECHNICAL REVIEW, No.188 (2006), pp.15-20 (in Japanese).

Shiigai, H., Paper balloon, harbor, and Torahiko Terada, Fluid mechanics note 9, NAGARE, The Japan Society of Fluid Mechanics, Vol.13, No.6 (1994), pp.479-482 (in Japanese).

Shin, R. S., Chou, C.-r. and Yim, J. Z., Numerical estimations of wave reflection coefficients for irregular waves over submerged obstacles, Proceedings of the 50th International Offshore and Polar Engineering Conference, Seoul, Korea (2005), pp.40-47.

Togawa, H. and Shimonoseki, M., Introduction to boundary element method by using PC (1983), Saiensu-sha Co., Ltd. Publishers (in Japanese).

Tsuchiya, Y. and Fujiki, S., Improvement of capacitance-type wave gauge and its application to wave observation, Disaster Prevention Research Institute Annals, Vol.B-2, No.28 (1985), pp.549-564 (in Japanese).

Yip, T. L. and Chwang, A. T., Water wave control by a pitching plate, ASCE Journal of Engineering Mechanics, Vol.123, No.8 (1997), pp.800-807.

Yu, X. and Chwang, A. T., Water waves above submerged porous plate, ASCE Journal of Engineering Mechanics, Vol.120, No.6 (1994), pp.1270-1282. 